\title{
PKM INDUSTRI TEMPE KELURAHAN BAKALANKRAJAN KECAMATAN SUKUN KOTA MALANG
}

\author{
Dana Marsetiya Utama ${ }^{1}$, Teguh Baroto ${ }^{1}$ \\ ${ }^{1}$ Jurusan Teknik Industri, Fakultas Teknik, Universitas Muhammadiyah Malang \\ dana@umm.ac.id
}

\begin{abstract}
ABSTRAK
Program Kemitraan Masyarakat (PKM) ini bertujuan untuk mempercepat waktu perebusan tempe dan meningkatkan manajemen keuangan usaha pada industri tempe di Kelurahan Bakalankrajan Kecamatan Sukun Kota Malang. Metode pelaksanaan kegiatan melalui Focus Group Discussion (FGD) dan metode Participatory Rural Apprasial (PRA). Tahapan pelaksanaan kegiatan adalah (1) Perancangan dan pembuatan alat high pressure cooker, (2) Pelatihan dan pendampingan penggunaan alat high pressure cooker, (3) Memberikan formula perebusan kedelai dan kacang menggunakan alat high pressure cooker khususnya waktu perebusan yang optimal, dan (4) Pelatihan dan pendampingan manajemen keuangan usaha. Sasaran progam adalah Industri tempe "Londho" dan "barokah". Kesuksesan Program Kemitraan Masyarakat (PKM) ditentukan berdasarkan peningkatan kuantitas produksi mitra, dan meningkatnya pengetahuan mitra tentang manajemen keuangan usaha. Program pertama adalah Desain alat high pressure cooker dilakukan di Laboratorium MATC UMM. Program kedua adalah memberikan formula lama perebusan dengan alat perebus khususnya waktu perebusan. Hasilnya menunjukan waktu perebusan optimal kedelai adalah 2 jam. Program ketiga yang diberikan berupa pelatihan manajemen keuangan usaha dan penggunaan. Pelatihan tersebut diikuti sepuluh peserta dari Industri tempe "Londho" dan "barokah". Hasilnya pelatihan tersebut menunjukan peningkatan pengetahuan dan keterampilan manajemen keuangan usaha dan penggunaan alat $(\mathrm{P}=0,012)$. Hasil ini menggambarkan bahwa program efektif untuk meningkatkan kuantitas produksi serta manajemen keuangan usaha..
\end{abstract}

Kata Kunci: Alat perebus, Kemitraan, Manajemen keuangan, Tempe

\section{PENDAHULUAN}

Tempe merupakan makanan tradisional yang digemari oleh masyarakat. Protein tinggi terkandung dalam makanan tempe (Shurtleff and Aoyagi, 1979). Tempe dihasilkan jamur rhizopus oligosporus yang fermentasi dengan bahan kacangkacangan (Haliza et al., 2016). Fermentasi dilakukan dengan mencampur kacang-kacangan dengan ragi tempe (rhizopus oligosporus). Kacang kedelai memiliki kandungan protein nabati yang baik (Ginting et al., 2009). Padatan putih dihasilkan dari fermentasi tersebut. Miselia jamur yang tumbuh pada permukaan biji kacangkacangan menyebabkan warna putih pada tempe (Halifah, 2011). Gizi yang terkandung dalam tempe adalah vitamin, mineral, serat, lemak, dan karbohidrat (Utari, 2010).

Home industry tempe "Londho" dan "Barokah" beralamatkan di Kelurahan Bakalankrajan sukun malang. Pada aspek produksi tempe, secara umum home Industry "Londho" dan "Barokah" mempunyai tahapan produksi yang sama. Tahap 1 proses produksi tempe kedelai dan kacang dimulai dengan melakukan pencucian bahan baku kacang dan kedelai. Tahap 2 diilakukan perendaman kedelai dan kacang selama 12 jam, kemudian dilanjutkan perebusan selama 45 jam. Tahap 3 melakukan pemecahan kedelai dan kacang serta pemisahan kulit ari dengan menggunakan mesin pemecah. Tahap 4 melakukan pembilasan kedelai hasil pemecahan dengan mesin pemecah agar kedelai dan kacang bersih tanpa kulit ari. Tahap 5 melakukan penirisan kedelai selama 6 jam. Tahap 6 melakukan peragian ke kedelai dan kacang. Tahap 7 proses fermentasi tempe dengan cara menempatkan kedelai dan kacang hasil peragian ke rak selama 24 jam.

Pada aspek manajemem pemasaranya, home Industry "Londho" home Industry "Barokah" masih mengandalkan proses pemasaran dari mulut ke mulut dan berusaha menjemput pelanggan (karyawa menawarkan produk tempe keliling ke masyarakat). Namun, seringkali kedua usaha tidak bisa memenuhi pesanan dari pelanggan tetap (pedagang sayur keliling dan pedagang pasar). Ketidak mampuan memenuhi pesanan dari pelanggan tetap disebabkan kapasitas produksi usaha yang relatif kecil. Pada aspek manajemen keuangan, perusahaan mencampur adukan pengeluaran perusahaan dan pengeluaran rumah tangga. Hal ini menyebabkan perusahaan tidak dapat menentukan harga jual tempe yang tepat serta belum dapat melihat arus kas dalam satu periode. Meskipun usaha ini masih bersifat mikro, namun pemilik usaha ini tetap optimis dalam 
menjalankan usahanya terbukti dengan keinginan kuat untuk mengembangkan usaha dengan meningkatkan kuantitas produksi, memperbaiki proses pengolahan, memperbaiki manajemen usaha dan memperluas pemasaran produk.

Kedua mitra seringkali kewalahan dengan pesanan pelanggan disebabkan karena kapasitas alat produksi yang terbatas dan peralatan proses yang manual sehingga produksi tidak dapat dilakukan secara efisien. Kedua mitra belum berani untuk menambah kapasitas produksi tempe. Hal ini disebabkan proses pembuatan tempe dari bahan baku kedelai dan kacang sampai menjadi tempe diperlukan waktu 2 hari. Produk tempe yang dibuat masih menggunakan metode pengolahan yang manual. Proses perebusan kedelai dan kacang menggunakan alat perebusan manual. Proses perebusan kedelai dan kacang membutuhkan waktu 4-5 jam apabila kedelai direndam selama 12 jam. Namun, apabila kedelai dan kacang tanpa dilakukan perendaman membutuhkan waktu perebusan selama 5-6 jam. Kapasitas alat perebusan kedua mitra sebesar $100 \mathrm{~kg}$. Kedua mitra melakukan proses perebusan kedelai dan kacang sebanyak 2 kali perebusan. Total waktu yang diperlukan kedua mitra untuk melakukan proses perebusan kedelai dan kacang 8-9 jam jam per hari. Masalah tersebut mengakibatkan kedua mitra tidak dapat memenuhi pesanan dari pelanggan.

Umumnya permasalahan mitra dibidang penjadwalan produksi (Harto et al., 2016, Nasution et al., 2017, Utama, 2017a) dan pengendalian persediaan (Utama, 2016, Utama, 2017b, Utama, 2017c). Namun, berdasarkan prioritas permasalahan yang telah disepakati antara mitra dan tim PKM maka solusi yang di tawarkan yang akan dicapai melalui program PKM ini adalah: (1) Teknologi tepat guna yaitu berupa alat high pressure cooker kedelai dan kacang sehingga kedua mitra bisa meningkatkan kuantitas dan kualitas produknya dan dapat mengurangi waktu proses perebusan. Teknologi alat high pressure cooker dipilih sebagai solusi dari permasalahan yang ada disebabkan dengan teknologi alat high pressure cooker yang tepat akan membuat proses produksi dilaksanakan dengan lebih efisien dan efektif. Bantuan teknologi alat high pressure cooker kedelai dan kacang juga dapat menghemat waktu serta bahan bakar yang digunakan perusahaan untuk proses perebusan yang awalnya satu kali perebusan membutuhkan waktu 4 jam dapat dihemat menjadi 1-1,5 jam. Penelitian terdahulu yang terkait dengan desain alat perebus dilakukan oleh Khuluqi (2012) dan Yuwono et al. (2007). Selain itu beberapa penelitian tentang efek penggunaan alat pressure cooker terhadap produk makanan diteliti oleh Tapotubun et al. (2008), Kariada and Aryadi (2010) dan Saparudin (2017). Penelitian tersebut menyimpulkan bahwa penggunaan alat pressure cooker dapat menjaga kualitas gizi makanan. (2) Formula perebusan kedelai dan kacang menggunakan alat high pressure cooker. Formula perebusan kedelai dan kacang dengan alat high pressure cooker di pilih sebagai solusi disebabkan untuk mendapatkan kualitas tempe yang baik diperlukan formula khusus dalam proses perebusan dengan alat high pressure cooker. Penelitian tentang pengaruh penggunaan pressure cooker terhada mutu produk dilakukan oleh Sri Pramita (2008), Tapotubun et al. (2008) dan Kariada and Aryadi (2010). Penelitian tersebut menyimpulkan bahwa penggunaan alat pressure cooker dapat menjaga kualitas gizi makanan. (3) Pelatihan dan pendampingan manajemen keuangan usaha. Solusi ini dipilih agar usaha industri tempe menerapkan manajemen keuangan yang baik. Dalam pelatihan dan pendampingan manajemen keuangan, tim pengabdian akan menggunakan acuan beberapa literatur buku yang membahas mengenai kewirausahaan manajemen keuangan usaha kecil diantaranya Weston et al. (1994), Brigham and Houston (2001), dan Syamsuddin (2007). Kegiatan pendampingan bertujuan untuk melihat keberhasilan penggunaan alat high pressure cooker dalam meningkatkan kuantitas produksi tempe dan dampaknya terhadap peningkatan omset penjualan. Kedua mitra pelatihan akan diberikan manual book penggunaan alat high pressure cooker.

\section{METODE}

Metode kegiatan Program Kemitraan Masyarakat (PKM) dapat dikategorikan menjadi beberapa tahap sebagai berikut: (1) Metode kegiatan yang di laksanakan dengan melakukan Focus Group Discussion (FGD) yaitu melakukan diskusi dengan kedua mitra. FGD digunakan untuk mengidentifikasi masalah mitra, menentukan prioritas masalah, dan memberikan solusi yang tepat bagi kedua mitra. Sedangkan metode Participatory Rural Apprasial (PRA) yaitu melibatkan kedua mitra dalam kegiatan. Pelaksanaan kegiatan ini melalui penyuluhan, pelatihan dan pendampingan serta evaluasi untuk melihat efektifitas program sehingga program tersebut akan berjalan dengan efektif.

Penerapan teknologi tepat guna akan dilakukan kegiatan perancangan dan pembuatan alat untuk proses perebusan kedelai dan kacang yaitu berupa alat high pressure cooker. Tahapan proses perancangan dan pembuatan alat high pressure cooker yang dilakukan oleh tim pengabdian sebagai berikut: (a) Analisis kebutuhan 
dalam perancangan alat high pressure cooker, (b) Analisis morfologi alat untuk menentukan fungsi alat dan komponen pembentuknya, (c) Diskusi dengan tim untuk menentukan tahap perancangan alat high pressure cooker, (d) Wawancara dengan mitra mengenai kapasitas alat yang diinginkan beserta karakteristik alat. (e) Penentuan dimensi alat high pressure cooker dan pembuatan gambar, (f) Pembuatan mesin di Laboratorium Proses Produksi, (g) Uji coba performansi alat high pressure cooker, (h) Serah terima alat high pressure cooker kepada mitra.

Memberikan formula perebusan kedelai dan kacang menggunakan alat high pressure cooker. Kegiatan dilakukan dengan melakukan uji eksperimental terhadap waktu proses perebusan kedelai dan kacang.

Pelatihan dan pendampingan manajemen keuangan usaha. Pelatihan yang diberikan adalah penyusunan arus dan perhitungan harga jual produk. Kegiatan penyuluhan dan pelatihan ini dilakukan 2 kali pertemuan. Kegiatan Pendampingan dalam mengelola keuangan kedua mitra selama 2 bulan dengan memberikan konsultasi kapanpun jika mereka membutuhkan masukan dan mengalami masalah serta kunjungan secara periodik. Selama pendampingan, tim pengabdian akan memonitor omzet penjualan kedua mitra untuk memastikan keberhasilan kegiatan pengabdian ini.

Pertisipasi mitra adalah mengikuti semua kegiatan peyuluhan, pendampingan dan pelatihan yang dilakukan oleh tim PKM serta memberikan kesempatan kepada yang terlibat didalam proses produksi yang dilakukan oleh kedua mitra untuk mengikuti pelatihan serta dapat mengimplementasikan hasil kegiatan..

Selanjutnya pengendalian program pengabdian dilakukan melalui kegiatan monitoring, pengawasan, evaluasi, pelaporan dan tindak lanjut terhadap pelaksanaan kegiatan. Pengendalian terhadap seluruh program ditujukan untuk: Memastikan seluruh tahapan kegiatan sesuai dengan program yang telah ditetapkan dan solusi yang ditawarkan ke mitra. Selain itu, Mengendalikan kegiatan agar sesuai dengan program yang telah ditetapkan.

Menjaga kualitas kegiatan sehingga dapat memenuhi indikator keberhasilan program yang diamati secara langsung dari output (luaran) yang telah diuraikan sebelumnya.

\section{PEMBAHASAN}

\subsection{Rancang Bangun High Pressure Coocker}

Tim pengabdi telah melakukan beberapa tahap dalam proses perancangan dan pembuatan alat high pressure cooker adalah (1) analisis kebutuhan dalam perancangan alat high pressure cooker dan diskusi dengan mitra mengenai alat dibutuhkan, (2) Analisis morfologi alat dan diskusi dengan tim untuk menentukan tahap perancangan alat high pressure cooker, (3) Proses pembuatan alat, (4) Uji performa alat. Kegiatan analisis kebutuhan dalam perancangan alat high pressure cooker dan diskusi dengan mitra mengenai alat dibutuhkan berlangsung pada 16 Mei 2018. Selanjutnya, kegiatan analisis morfologi alat dan diskusi dengan tim untuk menentukan tahap perancangan alat high pressure cooker dilakukan pada 21 Mei 2018. Desain alat high pressure cooker dilakukan di Laboratorium MATC UMM. Kegiatan proses pembuatan alat dimulai sejak tanggal pada 25 Mei 2018. Gambar alat perebus dapat dilihat pada Gambar 1.

\subsection{Uji kualitas kedelai dengan alat high pressure cooker}

Tim pengabdian melakukan percobaan untuk mengetahui kualitas kedelai produksi tempe. Penentuan kriteria yang digunakan untuk uji kualitas organoleptik selanjutnya melakukan focus group discussion. Focus group discussion dilakukan 6 orang (2 perwakilan konsumen, 2 pengusaha dan 2 pakar). Kegiatan ini berlangsung pada 25 Juni 2018. Tabel 1 menunjukan hasil focus group discussion dari tingkat kepentingan tiap-tiap kriteria organoleptik dengan menggunakan matriks pairwise comparison. Perhitungan AHP dilakukan dengan bantuan software expert choice 11 .

Tabel 1. Bobot dan rangking kriteria uji organoleptik berdasarkan AHP

\begin{tabular}{lcc}
\hline $\begin{array}{l}\text { Kriteria uji } \\
\text { organoleptik }\end{array}$ & Bobot & Rangking \\
\hline Warna & 0,066 & 5 \\
Rasa & 0,484 & 1 \\
Tekstur & 0,189 & 2 \\
Aroma & 0,189 & 3 \\
Bentuk & 0,072 & 4 \\
\hline
\end{tabular}

Konsistensi Rasio $=0,00846$

Tabel 1 menunjukan bobot untuk kriteria uji organoleptik berdasarkan AHP dari rangking tertinggi ke terendah adalah Rasa mempunyai bobot tertinggi dengan bobot 0,484. Tekstur dengan bobot 0,189 . Ketiga yaitu Aroma dengan bobot 0, 189. Keempat yaitu Bentuk dengan bobot 0,072. Dan Warna dengan bobot 0,066. Rasa mempunyai bobot yang paling tinggi. Hal ini menunjukan bahwa rasa menjadi faktor paling penting dalam uji organoleptik. Kemudian tim pengabdi membuat 2 alternalit lama perebusan 2 jam dan 3 jam. Hasil perangkingan alternatif lama perebusan dapat dilihat pada tabel 2 . 
Tabel 2 Hasil perangkingan alternatif lama perebusan terhadap kualitas uji organoleptik

\begin{tabular}{ccc}
\hline Rangking & $\begin{array}{c}\text { Alternatif Lama } \\
\text { Perebusan }\end{array}$ & Vi \\
\hline 1 & 2 Jam & 0,982 \\
2 & 3 Jam & 0,694 \\
\hline
\end{tabular}

Tabel 2 menunjukan hasil pengolahan data dengan metode SAW yang didapatkan hasil akhir rangking untuk tiap alternatif lama perebusan. Berdasarkan tingkat preferensi alternatif lama perebusan terhadap kualitas uji organoleptik didapatkan hasil akir rangking untuk tiap alternatif lama perebusan pertama didapatkan 2 Jam dengan total preferensi 0.982. Rangking kedua adalah alternatif lama perebusan 3 jam dengan total preferensi 0,694.

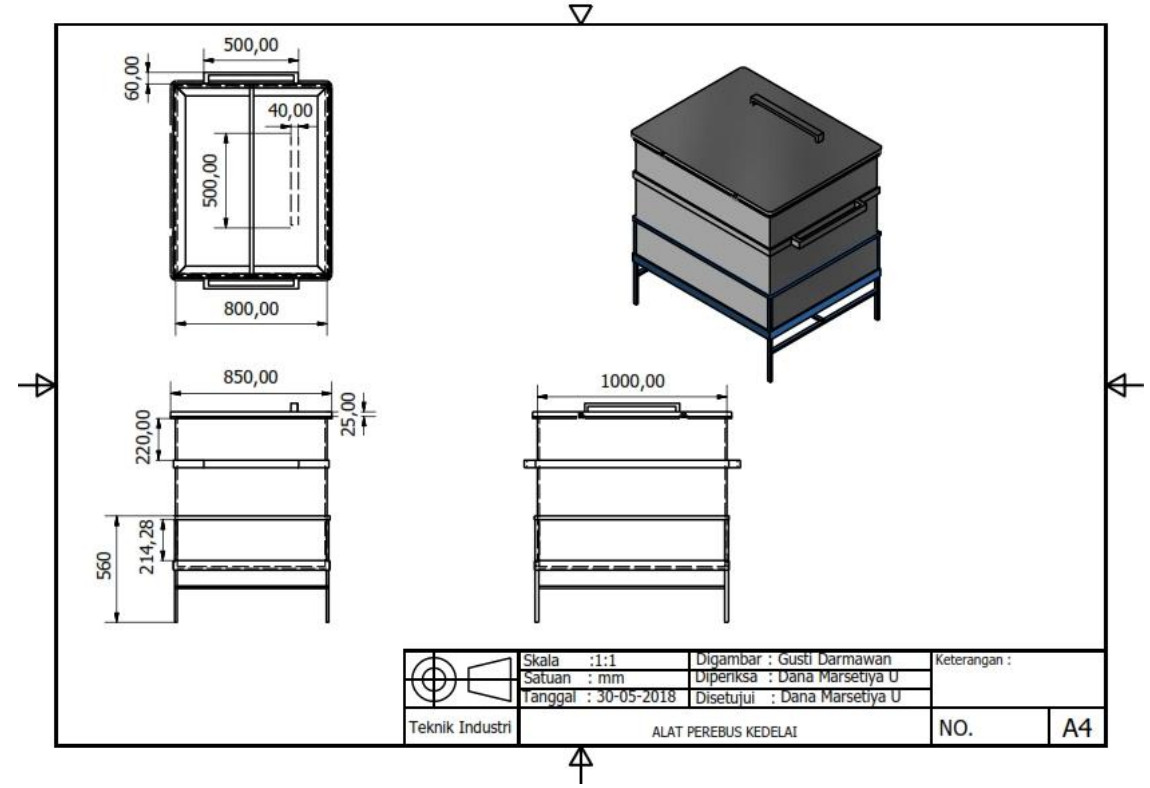

Gambar 1. Desain alat perebus kedelai high pressure

\subsection{Pelatihan Manajemen keuangan}

Pelatihan manajemen keuangan usaha dilaksanakan pada hari Sabtu, tanggal 21 juli 2018 jam 08.00 - 12.00 bertempat di rumah Ibu Sri Wahyuningsih yang dihadiri oleh 10 peserta. Peserta ini terdiri dari 2 orang yang berasal dari tim pengabdian dan 8 peserta berasal dari industri tempe. Pelatihan dimulai dengan penyampaian materi oleh Tim PKM dan selanjutnya tanya jawab. Pada kesempatan tersebut ada 2 materi yang disampaikan yaitu: 1) Komponen biaya pada usaha, dan 2) Harga Pokok Produksi. Kegiatan pelatihan dapat dilihat pada Gambar 2.
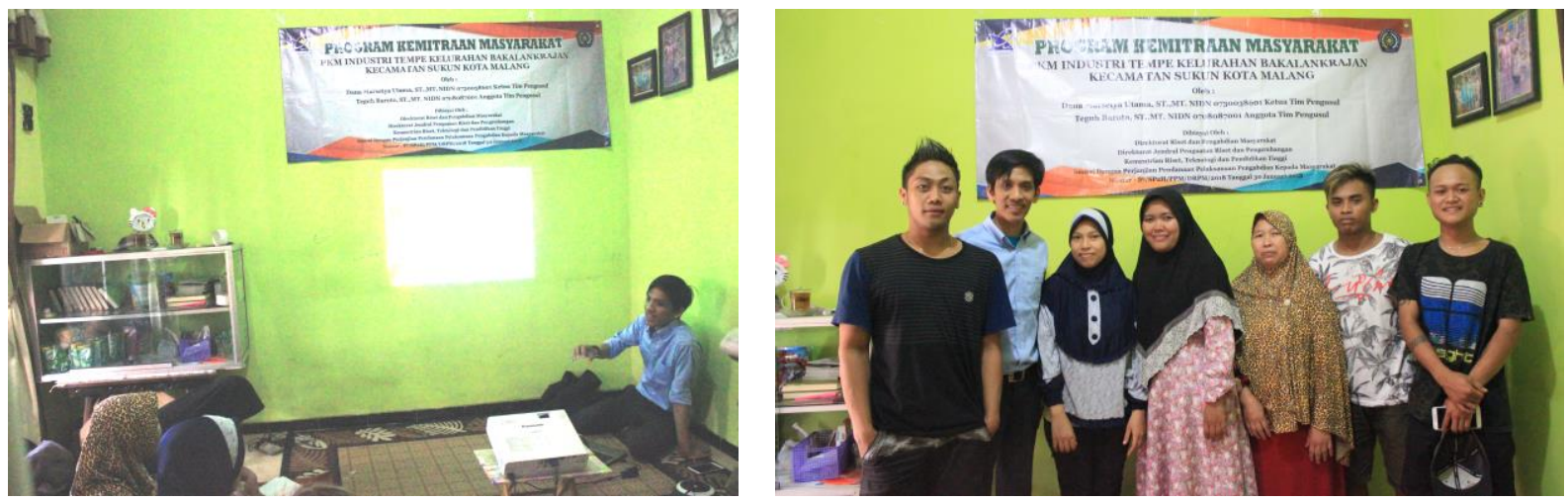

Gambar 2. Pelatihan manajemen keuangan usaha

Litbang Pemas Unisla

ISBN: 978-602-62815-4-9 
Evaluasi keberhasilan pelatihan dilakukan dengan uji pengetahuan dan uji keterampilan. Uji dilakukan untuk menganalisis signifikansi perubahan pengetahuan sebelum dan sesudah pelatihan. Keterampilan yang berkaitan dengan 1) Komponen biaya pada usaha, dan 2) Harga Pokok Produksi. Ceklis keterampilan digunakan sebagai pedoman penilaian. Setelah pelatihan usai kemudian dilakukan uji keterampilan melakukan perhitungan Harga Pokok Produksi. Pengetahuan peserta pelatihan meningkat secara signifikan $(p=0,012)$. Hal itu dapat dilihat dari perubahan nilai rata-rata ketika menjawab soal 1) Komponen biaya pada usaha, dan 2) Harga Pokok Produksi. Hasil uji Wilcoxon dapat dilihat pada Tabel

Tabel 3. Hasil Uji Wilcoxon Pengetahuan peserta pelatihan

\begin{tabular}{|c|c|c|c|c|c|}
\hline Pengetahuan & $\mathbf{N}$ & Mean & $\begin{array}{r}\text { Std. } \\
\text { Deviation }\end{array}$ & $\mathbf{Z}$ & $\begin{array}{r}\text { Asymp. Sig. } \\
\text { (2-tailed) }\end{array}$ \\
\hline Sebelum & 8 & 14,1250 & 1,64208 & $-2,527^{b}$ & 0,012 \\
\hline Sesudah & 8 & 21,1250 & 1,12599 & & \\
\hline
\end{tabular}

\subsection{Pemberian Bantuan Fisik Berupa Mesin}

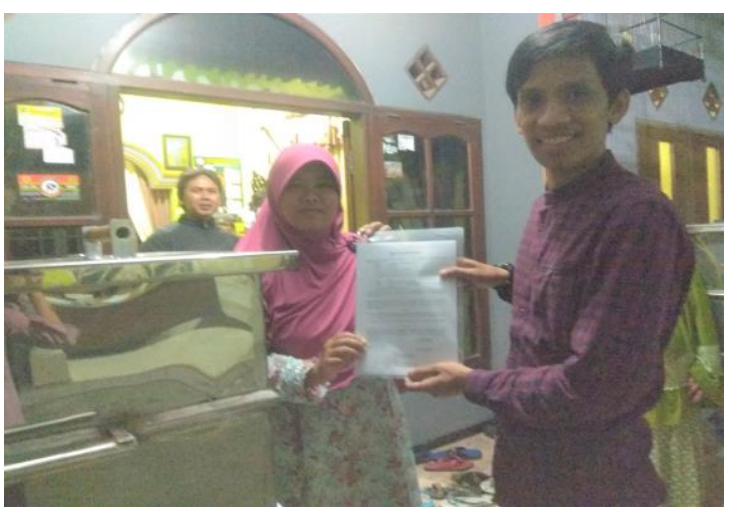

(a)

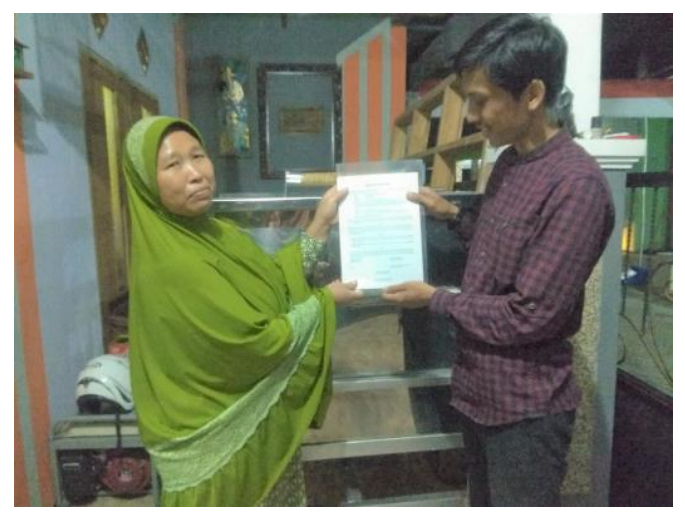

(b)

Gambar 3 Serah terima alat (a) untuk industri tempe "Londo" (b) untuk industri tempe "Barokah

Serah terima program diseminasi teknologi ke masyarakat dan untuk dapat mengimplementasikan barang/peralatan berupa : "Alat Perebus High Pressure" yang diperoleh dari kegiatan Diseminasi Produk Teknologi ke Masyarakatdan kepada mitra. Serah terima serah terima alat ke kedua mitra. Serah terima telah dilakukan pada tanggal 27 Juli 2018 pada pukul 19:00. Penyerahan dilakukan di rumah Ibu Sri Wahyuningsih. Serah terima alat ini bertujuan agar mitra dapat meningkatkan volume produksi. Dokumentsi serah terima alat dapat dilihat pada gambar 3 .

\section{KESIMPULAN}

Dari kegiatan yang sudah dilakukan menunjukan bahwa kegiatan pengabdian dapat memberikan dampak yang cukup signifikan kepada kedua mitra. Namun, tim PKM perlu melakukan kegiatan lebih lanjut untuk memastikan mitra dapat memperbaiki kegiatan produksi dan manajemen.

\section{UCAPAN TERIMA KASIH}

Ucapan terimakasih kepada KEMENRISTEKDIKTI yang telah membiayai program Pengabdian Kepada Masyarakat Tahun Anggaran 2018 sesuai dengan surat nomor: 0047/E3/LL/2018 dan Universitas Muhammadiyah Malang yang memberikan dukungan dalam pelaksanaan Program Kemitraan Masyarakat.

\section{REFERENSI}

Brigham, E. F. \& Houston, J. F. 2001. Manajemen Keuangan. Buku 1 edisi 8. Jakarta: Erlangga.

Ginting, E., Antarlina, S. S. \& Widowati, S. 2009. Varietas unggul kedelai untuk bahan baku 
industri pangan. Jurnal Litbang Pertanian, 28, 79-87.

Halifah, P. 2011. Pengaruh lama perebusan terhadap kadar protein tempe kacang tunggak (Vigna unguiculata). bionature, 12.

Haliza, W., Purwani, E. Y. \& Thahir, R. 2016. Pemanfaatan kacang-kacangan lokal sebagai substitusi bahan baku tempe dan tahu. Buletin Teknologi Pasca Panen, 3, 1-8.

Harto, S., Garside, A. K. \& Utama, D. M. 2016. Penjadwalan Produksi Menggunakan Algoritma Jadwal Non Delay untuk Meminimalkan Makespan Studi Kasus Di CV. Bima Mebel. Spektrum Industri, 14.

Kariada, N. \& Aryadi, W. 2010. Uji Kualitas Bandeng Presto Dengan Alat Low Temperatur High Pressure Cooker (LTHPC). Sainteknol: Jurnal Sains dan Teknologi, 8.

Khuluqi, R. 2012. Prototype Perebus Ayam Otomatis pada Produksi Makanan Berbasis Atmegal6. Tugas Akhir, Universitas Negeri Malang.

Nasution, R., Garside, A. K. \& Utama, D. M. 2017. Penjadwalan Job Shop Dengan Pendekatan Algoritma Artificial Immune System. Jurnal Teknik Industri, 18, 2942.

Saparudin, D. W. 2017. Validasi Simulasi Tekanan Dan Suhu Air Serta Suhu Daging Sapi Selama Pemasakan Dalam Pressure Cooker. Jurnal Teknologi Industri Pertanian, 26.

Shurtleff, W. \& Aoyagi, A. 1979. The book of tempe, a super soyfood from Indonesia. Harper \& Row. New York.

Sri Pramita, D. 2008. Pengaruh teknik pemanasan terhadap kadar asam fitat dan aktivitas antioksidan koro benguk (mucuna pruriens), koro glinding (phaseolus lunatus), dan koro pedang (canavalia ensiformis). Disertasi, Universitas Sebelas Maret.

Syamsuddin, L. 2007. Manajemen Keuangan Perusahaan: Konsep Aplikasi dalam Perencanaan, Pengawasan, dan Pengambilan Keputusan, Jakarta, PT. Raja Grafindo Persada.

Tapotubun, A., Nanlohy, E. \& Louhenapessy, J. 2008. Efek waktu pemanasan terhadap mutu presto beberapa jenis ikan. Jurnal Ichthyos, 7, 65-70.

Utama, D. M. 2016. Penentuan Lot Size Pemesanan Bahan Baku Dengan Batasan Kapasitas Gudang. Jurnal Ilmiah Teknik Industri, 15, 64-68.

Utama, D. M. 2017a. Analisa Perbandingan Penggunaan Aturan Prioritas Penjadwalan Pada Penjadwalan Non Delay N Job 5 Machine. Research Report, 1.

Utama, D. M. 2017b. Model Penentuan Lot Pemesanan Dengan Mempertimbangkan Unit Diskon dan Batasan Kapasitas Gudang dengan Program Dinamis. Jurnal Teknik Industri, 18, 94-102.

Utama, D. M. Model Program Dinamis Dalam Penentuan Lot Pemesanan dengan Mempertimbangkan Batasan Modal. Prosiding SENTRA (Seminar Teknologi dan Rekayasa), 2017c.

Utari, D. M. 2010. Kandungan Asam Lemak, Zink, Dan Copper Pada Tempe, Bagaimana Potensinya Untuk Mencegah Penyakit Degeneratif. Gizi Indonesia, 33.

Weston, J. F., Kirbtandoko, Wasana, A. J. M., Dipokusumo, S. \& Copeland, T. E. 1994. Manajemen keuangan, Erlangga.

Yuwono, T., Mughni, D. \& Budioko, T. 2007. Rancang Bangun Pengontrol Suhu dan Level Air pada Alat Perebus Kepompong Ulat Sutra. Jurnal Logika, 4. 